\title{
ОЦІНКА ВАРІАБЕЛЬНОСТІ СЕРЦЕВОГО РИТМУ ПРИ ВИКОНАННІ ТЕСТОВИХ ЗАВДАНЬ З ПІДТРИМКИ ВЕРТИКАЛЬНОЇ ПОЗИ
}

\author{
Ю. Є Лях, Ю. Г. Вихованець, А. М. Черняк, В. І. Остапенко, О. В. Лахно \\ Донецький національний медичний університет ім. М. Горького
}

\begin{abstract}
Исследованиями установлено, что при выполнении различных двигательных задач при поддержании вертикальной позы изменяется тонус вегетативной нервной системы. Характер изменения изучаемых показателей вариабельности сердечного ритма при проведении тестов в различных условиях сенсорного контроля зависит от функционального состояния обследуемых. На основе полученных данных разработана методика прогнозирования риска возникновения неблагоприятных функциональных состояний.
\end{abstract}

При вивченні механізмів регуляції вертикальної пози (ВП) важливою задачею є оцінка показників, що характеризують діяльність різних функціональних систем організму які приймають участь у формуванні рухів людини [1,3,5]. Загальновідомо, що значну частку у формуванні функціональних станів людини займають процеси вегетативної регуляції, які оцінюють за показниками варіабельності серцевого ритму (BCP). Парасимпатичний і симпатичний відділи вегетативної нервової системи, взаємодіючи між собою, здійснюють регуляцію серцевого ритму, який, як відомо, може змінюватись при захворюваннях серцево-судинної системи, різних функціональних розладах. Це доводить необхідність вивчення ВСР у осіб з різним функціональним станом. Для оцінки процесів регуляції серцевого ритму при виконанні тестових завдань 3 підтримки вертикальної пози (ВП) проводилася реєстрація показників варіабельності серцевого ритму (ВСР). Необхідно додати, що при проведенні цифрової реєстрації R-R інтервалів можуть виникати проблеми, пов'язані з дією різноманітних фізичних факторів на якість цифрового запису сигналів, що значно ускладнює проведення їх аналізу [1]. Тому важливою задачею $є$ розробка методики фільтрації та аналізу кардіосигналів.

Метою досліджень було удосконалення методики фільтрації і аналізу біосигналів та оцінка показників ВСР у осіб з різним функціональним станом при проведенні стабілометричних тестів.

Дослідження проводили на базі психофізіологічної лабораторії кафедри медичної, біологічної фізики, медичної інформатики і біостатистики ДоНМУ ім. М. Горького. Реєстрацію електрофізіологічних показників (стабілограм, електрокардіограм) здійснювали з використанням комп'ютерного комплексу «Поліграф» $[4,6]$. Проводили стабілометрічні тести в різних умовах сенсорного навантаження. Для цього було проведено тестування, що складалося 3 трьох частин: зі штучним зворотним зв' язком (ШЗ3), з відкри- тими очима (BO) та із заплющеними очима (3О). Оцінка варіабельності серцевого ритму здійснювалася за даними кардіоінтервалограм, отриманих при проведенні стабілометричних тестів. Перешкоди, що утворюються при проведенні цифрових записів ЕКГ, усували за допомогою смугового фільтра, побудованого на основі розкладання сигналу в ряд Фур'є. Розкладання сигналу в цей ряд проводили за алгоритмом швидкого перетворення Фур' $\epsilon$, що дозволяло обробляти сигнал і в режимі реального часу. Кожен запис включав більше 100 кардіоінтервалів. Програмно проводився розрахунок наступних показників: стандартне відхилення всіх RR-інтервалів (SDNN); квадратний корінь із середньої суми квадратів різниць між сусідніми RR-інтервалами (RMSSD); кількість пар послідовних інтервалів (NN50); відсоток NN50 від загальної кількості послідовних пар інтервалів, що розрізняються більше, ніж на 50 мілісекунд, отриманих за увесь період запису (PNN50 (\%)); індекс напруження регуляторних систем (IH); індекс вегетативної рівноваги (IBP); вегетативний показник ритму (ВПР); показник адекватності процесів регуляції (ПАПР); загальна кількість R-R інтервалів (N); середній період кардіоциклів (T); частота серцевих скорочень (F).

Було обстежено 269 осіб віком від 17 до 70 років, серед яких виявилося 116 досліджуваних жіночої статі і 153 - чоловічої. 3 них було сформовано дві групи: контрольну та дослідну. У контрольну групу увійшли практично здорові особи, які не мали на момент досліджень гострих та загострень хронічних захворювань. У дослідну групу увійшло 105 осіб (чоловіків72 , жінок - 33) з різними пограничними станами, у структурі яких головне місце займали захворювання нервової системи та системи кровообігу в стадії клінічної ремісії.

При тестуванні в умовах з ШЗЗ у чоловіків контрольної групи частота серцевих скорочень $(\mathrm{F})(\mathrm{Me} \pm$ m $(25 ; 75 \%)$ ум. од.) коливалась у межах від $74,9 \pm 3,5$

(C) Ю. Є. Лях, Ю. Г. Вихованець, А. М. Черняк та ін. 
$(68,5 ; 90,7)$ до $87,6 \pm 9,4(82,7 ; 90,9)$ хв$^{-1}$. У дослідній групі F змінювалась від $71,6 \pm 6,9(65,6 ; 79,9)$ до $83,0 \pm 7,3$ $(62,5 ; 95,1)$ хв$^{-1}$. Статистично значущих відмінностей між групами за $\mathrm{F}$ не виявлено. Загальна потужність спектра RR-інтервалів (SDNN) у чоловіків контрольної групи змінювалася від 49,9 $9 \pm 3,8,3$ (23,7;

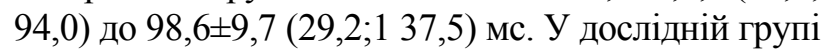
SDNN коливався в межах від 42,5 $\pm 3,9(32,2 ; 110,5)$ до $165,0 \pm 16,9(48,2 ; 251,7)$ мс. Дослідженнями встановлено збільшення SDNN у осіб, які страждають на захворювання системи кровообігу, у порівнянні 3 контрольною групою $(p<0,05)$. Індекс напруження регуляторних систем (IH) у чоловіків контрольної групи змінювався від 46,2 5 5,5 $(35,6 ; 62,2)$ до $87,2 \pm 11,5$ $(69,7 ; 127,6)$ ум. од. У дослідній групі він коливався в

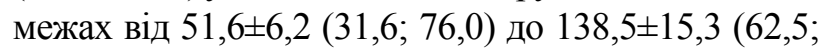
$175,2)$ ум. од. Встановлено збільшення ІН у осіб, які мають захворювання нервової системи, у порівнянні 3 контрольною групою $(\mathrm{p}<0,05)$.

У жінок контрольної групи $\mathrm{F}$ коливалась у межах

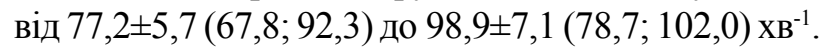
У дослідній групі $\mathrm{F}$ змінювався від $59,9 \pm 4,3(59,3 ; 74,7)$ до $81,6 \pm 7,9(76,4 ; 90,6)$ хв$^{-1}$. Показник SDNN у жінок контрольної групи змінювався від $74,7 \pm 3,8(43,1 ; 150,8)$ до $201,4 \pm 10,6(73,9 ; 315,3)$ мс. У дослідній групі він коливався в межах від $84,6 \pm 3,9(37,4 ; 94,5)$ до $281,6 \pm 20,7(217,6 ; 437,0)$ мс. Встановлені значущі відмінності $(\mathrm{p}<0,05)$ за SDNN між контрольною групою та особами, які мають захворювання нервової системи і системи кровообігу. Дослідженнями вста-

\section{Література}

1. Автоматизированная система выделения и анализа R-R интервалов при цифровой записи ЭКГ / Ю. Е. Лях, В. Г. Гурьянов, Ю. Г. Выхованец [и др.] // Архив клинической и экспериментальной медицины. - 2002. - Т. 11, № 3.С. 318-320.

2. Анализ стабилограмм у лиц с нарушениями координации движений / Ю. Е. Лях Ю. Г. Выхованец, О. Г. Горшков, С. А. Реброва // Университетская клиника. - 2009. - Т.5, № 1-2. - C. 99-102.

3. Аналіз регуляції вертикальної пози при стоянні на нерухомій платформі / Ю. С. Лях, Ю. Г. Вихованець, В. Г. Гур’янов, А. М. Черняк // Нейронауки: теоретичні та клінічні аспекти. -2010 . - Т. 6, № 1.-С. 96-100. новлено збільшення SDNN у осіб із захворюваннями нервової системи та системи кровообігу, у порівнянні $з$ контрольною групою $(\mathrm{p}<0,05)$. Індекс напруження регуляторних систем у жінок контрольної групи змінювався від 50,9 $44,6(45,4 ; 85,3)$ до $66,7 \pm 5,2$ $(38,8 ; 136,8)$ ум. од. У дослідній групі він коливався в межах від $35,8 \pm 3,8(35,3 ; 87,4)$ до 54,5 44,3 $(38,9 ; 67,1)$ ум. од. Аналогічні закономірності при аналізі ВСР були отримані при проведенні стабілометричних тестів з відкритими та заплющеними очима.

Висновки. При виконанні рухових задач з підтримки ВП змінюється тонус ВНС в залежності від типу тестування та функціональних і органічних порушень, що підтверджується результатами оцінки показників ВСР. У дослідженнях із ШЗ3 встановлено збільшення значень SDNN, IH, ПАПР у чоловіків із захворюваннями нервової системи та кровообігу, у порівнянні 3 контрольною групою $(\mathrm{p}<0,05)$. Виявлено збільшення SDNN, ПАПР у жінок, які мають захворювання нервової системи та кровообігу у порівнянні з контрольною групою $(\mathrm{p}<0,05)$. Аналогічні закономірності при аналізі показників ВСР були отримані при виконанні тестів з відкритими та заплющеними очима.

На основі отриманих показників здійснюється прогнозування ризику появи небажаних ФС при проведенні скринінгових обстежень населення, поточного та щорічного медичного огляду працівників підприємств, а також для індивідуалізації навчального процесу на основі моніторингу ФС студентів у навчальних закладах.

4. Вихованець Ю. Г. Комп’ютерний комплекс для кількісної біомедичної оцінки / Ю. Г. Вихованець // Вестник гигиены и эпидемиологии. -2008. - Т. 12, № 1.-С. 176-180.

5. Выхованец Ю. Г. Оценка антропометрических и физиологических показателей у лиц с различными функциональными и органическими нарушениями / Ю. Г. Выхованец // Вестник гигиены и эпидемиологии. - 2010. - Т. 14, № 1.C. 159-164.

6. Програмно-апаратний комплекс для біомедичних досліджень / Ю. С. Лях, Ю. Г. Вихованець, В. Г. Гур'янов, А. М.Черняк // Медична інформатика та інженерія. - 2008. -№ 1.-C. 9-13. 